\title{
The Thirtieth Annual Report of the Council
}

\section{President M. Gaster}

To cite this article: President M. Gaster (1908) The Thirtieth Annual Report of the Council, Folklore, 19:1, 5-11, DOI: 10.1080/0015587X.1908.9719806

To link to this article: http://dx.doi.org/10.1080/0015587X.1908.9719806

$$
\text { 曲 Published online: } 14 \text { Feb } 2012 .
$$

Submit your article to this journal

LII Article views: 1

Q View related articles $₫$ 


\title{
THE THIRTIETH ANNUAL REPORT OF THE COUNCIL.
}

\author{
15 TH JANUARY, IgO8.
}

THE Council are glad to record that the numbers of the Society are well maintained. Five libraries have been added as subscribers, and twenty-two new members have been elected. On the other hand twenty old members have resigned, and one has died; and the subscription of one library has been withdrawn. There is, therefore, a net gain of five on the roll of the Society. A smaller number of members than usual are in arrear with their subscriptions; but greater regularity in the payment of subscriptions is much to be desired. Thoughtfulness in this respect on the part of members would relieve the Secretary of much ungrateful work.

In the list of members published during the past year, a distinction has for the first time been drawn between ordinary members and libraries and other institutions of a similar nature subscribing to the funds of the Society; and the year in which the first subscription was paid is now printed opposite the name of each member and library or other institution. This change was foreshadowed by the Council in their last report. 
- Three members of the Society have been appointed Professors during the year, viz.: Dr. J. G. Frazer, for whom a Chair of Social Anthropology has been instituted in the University of Liverpool; Mr. J. C. Myres to the Chair of Greek in the same University; and Dr. E. Westermarck to the recently-founded Martin White Professorship of Sociology in the University of London.

The papers read during the year have been as follows:

Jan. 16. The President's Address. (Folk-Lore, March, 1907.)

Feb. 20. "L'Ar, or the Transference of Traditional Curses in Morocco." Dr. Westermarck.

March 20. "Well Cures and Children." Dr. Dan M'Kenzie.

April 17. "Some Notes from New Guinea" (illustrated by lantern slides). Dr. C. G. Seligmann.

May 15. "Homeric Folklore." Mr. W. Crooke.

"A Danish Survival." The Rev. H. F. Feilberg.

June 19. "Death's Deeds : a Bi-located Story." Mr. A. Lang.

Nov. 20. "Local Traditions of the Quantocks." The Rev. C. W. Whistler.

Dec. 18. "The Principles of Fasting." Dr. Westermarck.

The meetings were usually well attended, and the discussions which followed the reading of the papers were very suggestive.

The Council have to thank Mr. A. R. Wright for so kindly contributing to the success of the meetings in February and June by exhibiting on the former occasion a most interesting collection of Mohammedan amulets, and on the latter a number of objects used by secret societies in West Africa. Other objects exhibited during the year were some charms against the evil eye illustrating Dr. Westermarck's paper on Morocco, and a Lincolnshire charm of bog oak made by a farm lad to give to his sweetheart, which was kindly lent by Miss Mabel Peacock. The Council hope that members generally will 
bear in mind how much the exhibition of objects adds to the attractiveness and the scientific value of the Society's evening meetings. The Council take this opportunity of expressing their great regret that, owing to unforeseen circumstances, time did not admit of Mr. and Mrs. Townshend exhibiting the photographs of Pueblo Ceremonial Dances, which they had brought up with them from Oxford at the May meeting.

The Council rejoice to report that a scheme is now on foot for the erection of a new Museum of Archaeology and Ethnology at Cambridge, which, when carried out, will allow the objects belonging to the Society being seen to better advantage than is possible under the existing conditions. The compilation of a catalogue of these objects referred to in the last report is still under consideration.

The library of the Society, which is open to consultation by its members, together with that of the Royal Anthropological Institute at 3 Hanover Square, has received during the year some additions of a miscellaneous character.

The Society has issued during the year the 18 th volume of Folk-Lore. Miss Burne has again placed her invaluable services at the disposal of the Council as editor of the journal, and the warmest thanks of the Society are due to her for the able way in which she has discharged her task. The Society is again indebted to Mr. A. R. Wright for the index; and the Council have to place on record their appreciation of the service he has once more rendered to the Society by this compilation.

Arrangements have been made with the Council of the Royal Anthropological Institute for issuing a joint Annual Bibliography. The Council have observed with satisfaction that the Bibliography for 1905 has been well received by the press and the public. The Bibliography 
for 1906 will be issued at an early date; and will in the opinion of the Council be found still more acceptable, being twice the size of the former issue. Copies will be supplied to members and subscribers on application.

The additional volumes for 1904 and 1905, viz., Jamaican Song and Story, by Mr. Walter Jekyll, and Popular Poetry of the Baloches, by Mr. M. Longworth Dames, have been issued during the year. The Council of the Royal Asiatic Society have co-operated with the Council in the production of the latter volume, and have purchased 300 copies.

The Council have in hand the collection of Lincolnshire Folk-Lore from printed sources made by Miss Peacock and Mrs. Gutch, which it is proposed to issue as the additional volume for 1906, and a monograph entitled The Grateful Dead, by Mr. G. H. Gerould, which will probably be the additional volume for 1907 .

At the meeting of the Congress of Archaeological Societies held in July (at which the Society was represented by its President, Dr. Gaster, and other members), a resolution was carried on the motion of Mr. Nutt, seconded by Sir E. W. Brabrook, that that Congress should ask its component societies to assist the FolkLore Society in the collection of all that was in print on the subject of Folk-lore in their respective counties. Steps are being taken to give effect to this resolution.

In the course of 1908 the Society will complete its thirtieth year. It is proposed to celebrate the event by holding commemorative meetings extending over three days between the middle and end of July, to which eminent students of Folk-lore from all parts of the world will be invited. Full particulars of the time and place of these meetings, and of the subjects to be discussed at them, will be sent to members at as early a date as possible.

The Society was represented at the meeting of the 


\section{Annual Report of the Council.}

British Association at Leicester by Sir E. W. Brabrook, Mr. E. S. Hartland, and others.

The Council submit herewith the annual accounts and balance sheet duly audited. The balloting list for the Council and officers of the Society for the ensuing year is also sent herewith.

M. GASTER,

President. 


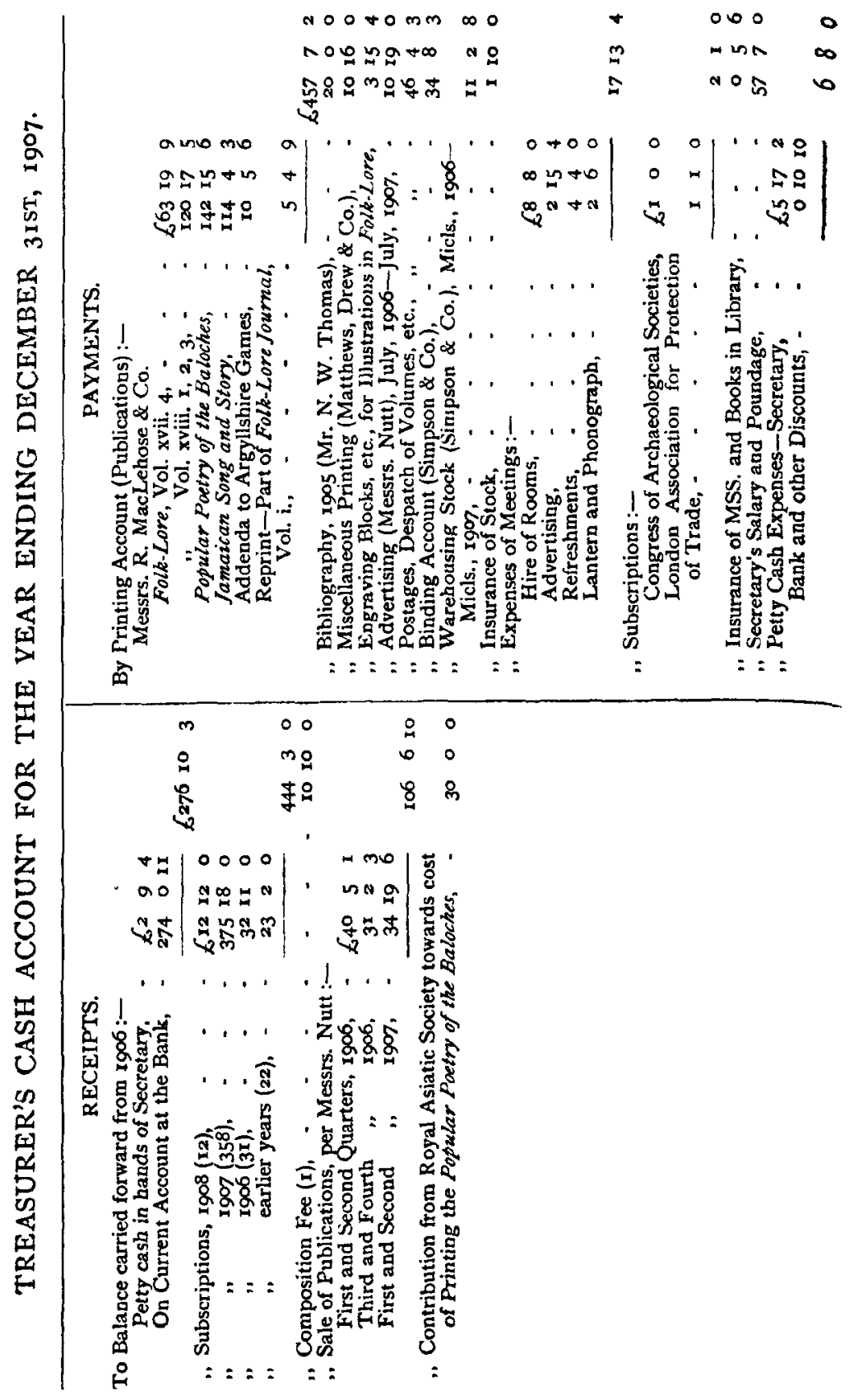




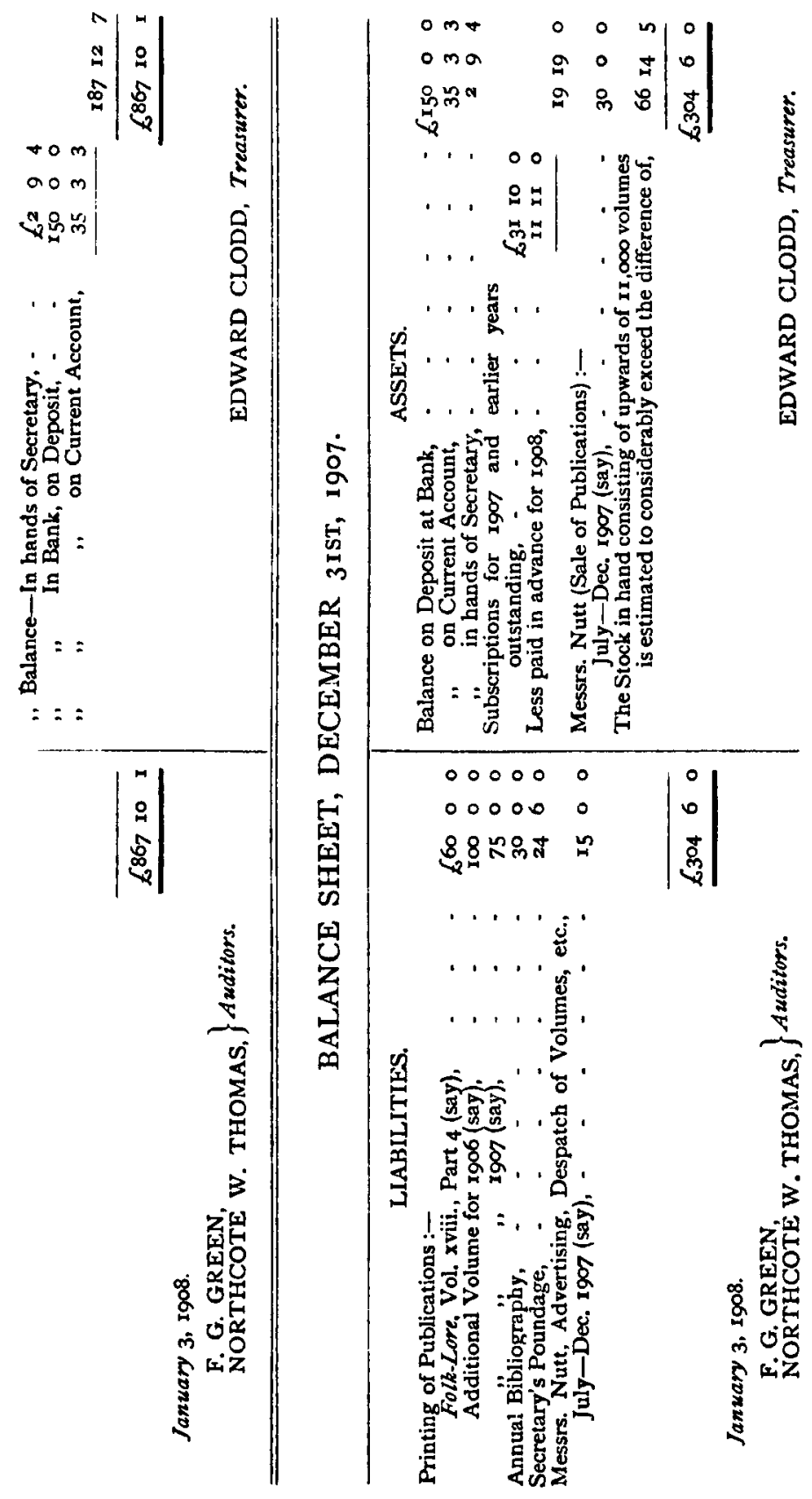

